\title{
Microbiological Identification of Bacteria with Leukemic Children
}

\author{
Huda Sahib Abdul-Mohammed Al-Rawazq ${ }^{1 *}$ (D), Ali Kamal Mohammed² and \\ Asifa Ali Hussein ${ }^{2}$
}

${ }^{1}$ Department of Anatomy, Biology Section, College of Medicine, University of Baghdad, Baghdad, Iraq. ${ }^{2}$ Central Teaching Hospital of Pediatric, Baghdad, Iraq.

\begin{abstract}
The most common form of childhood cancer is leukemia, Calculation for more than one third of all childhood cancers among those ages 1 day - 14 years. The diseases of leukemia are worldwide, it occurred in both genders from male and females and in all age. A total of 80 different samples of patient children were collected from the central teaching hospital of pediatric in Baghdad. Obtained during the period from 1st Sept. 2019 till the 31 th of Aug. 2020. Each isolates identification by using Vitek 2. Isolated organism in leukemic children show 18 (22.5\%) gram positive and 62 (77.5\%) gram negative from the total sample $\mathbf{8 0}(\mathbf{1 0 0 . 0} \%)$. The percent of male is 45 more than female which represents 35 in most age groups between age (1 day-3 year) 33 (100.0\%). In most distribution of organism according to the type of sample for gram positive is Staphylococcus aureus $13(16.2 \%)$ and gram negative Escherichia coli 21 (26.3\%), Klebsiella pneumoniae 13 (16.2\%), Pseudomonas aeruginosa 11 (13.8\%) from the total results $80(\mathbf{1 0 0 . 0} \%)$. In Conclusion, the gram negative bacteria is more than gram positive bacteria and especially effect with Escherichia coli, and Staphylococcus aureus, in males for the age group 1 day to 3 years. And the most antibiotic sensitive to Escherichia coli is Imipenem, Amikacin, Gentamycin, Piperacillin/Tazobactam and resist to Cefotazidime, Tobramycin, Cefepime, Ceftriaxone, Ciprofloxacin and Staphylococcus aureus most sensitive to Vancomycin, Gentamycin, Clindamycin, and resist to Penicillin, Cefotaxime, Ceftriaxone, Oxacillin.
\end{abstract}

Keywords: Microbiological Identification, Leukemic diseases, Children, bacteria, Antibiotic Sensitivity

\footnotetext{
*Correspondence: Hudasahib_2015@Yahoo.com

(Received: August 17, 2021; accepted: January 11, 2022)

Citation: Al-Rawazq HSA-M, Mohammed AK, Hussein AA. Microbiological Identification of Bacteria with Leukemic Children. J Pure Appl Microbiol. 2022;16(1):394-401. doi: 10.22207/JPAM.16.1.34

(C) The Author(s) 2022. Open Access. This article is distributed under the terms of the Creative Commons Attribution 4.0 International License which permits unrestricted use, sharing, distribution, and reproduction in any medium, provided you give appropriate credit to the original author(s) and the source, provide a link to the Creative Commons license, and indicate if changes were made.
} 


\section{INTRODUCTION}

The most common form of childhood cancer is leukemia, Calculation for more than one third of all childhood cancers among those ages 1 day -14 years. ${ }^{1}$ The diseases of leukemia are worldwide, it occurred in both genders from male and females and in all age. ${ }^{2}$ Determined the clinical presentations of infections through a complex interaction between the virulence, pathogen, and the defense mechanisms of the host and the degree to impaired. ${ }^{3}$ Patients with previously untreatable illness may now receive therapy and survive, due to large advances have been done in the management of patients with cancers. ${ }^{4}$ Most important reasons for morbidity and mortality in leukemia is bacterial infections. ${ }^{5} \mathrm{~A}$ divers set of chromosomal and molecular changes originate in pediatric leukemia, most of proof are acquired not inherited as only $5 \%$ of leukemia are associated with inherited syndromes. ${ }^{6}$ Leukemic relapses in the early decades of therapy for childhood acute lymphoblastic leukemia (ALL) was recognized in central nervous system. ${ }^{7}$ In patient who receives cancer treatment, blood stream infection is one of the major causes of morbidity and mortality. ${ }^{8}$ In leukemic patients receiving chemotherapy, particularly bacteremia is the basic factor for life-threatening, In spite of development in antibiotics therapy and health care; Especially in malignant disease including leukemia; Because of complication resulted from these infection, which still one of the therapeutics as a result challenges to immune system defect which causing deficiency in immunity, also because of little using of prophylactics therapy. ${ }^{9-11}$ Although evolution in antibiotics therapy, it remain the basic reason for mortalities in hospitalized patients chiefly critically ill patients like leukemia patients. ${ }^{12}$ In acute medical condition the semi-pathogen and normal microflora organisms can play important role. ${ }^{13}$ Higher mortality associated with polymicrobial was found $15-25 \%$ of bacteremia infections in cancer patients. ${ }^{8}$ Fever during chemotherapy induce neutropenia can be the first sign of bacterial infection. ${ }^{14}$ The neutropenic patients developing fever during neutropenia is a recurrent complication, Affecting $80 \%$ of those with hematological malignancies. ${ }^{15}$ In cancer patients for the choice of an effective empirical therapy or prophylaxis the important result is to increase of resistant bacteria. ${ }^{16,17}$ Excessive antibiotic exposure is also the most important agents influencing the emergence and prevalence of antibiotic resistance. ${ }^{18}$

\section{METHODS}

A total of 80 different samples of patient children were collected from the central teaching hospital of pediatric in Baghdad. Obtained during the period from $1^{\text {st }}$ Sept. 2019 till the $31^{\text {st }}$ of Aug. 2020. Data was collected by using questionnaire sheet concerning their [ages from ( 1 days -15 years), sex, type of sample, diagnosis and antibiotic sensitivity.

The identification of each isolates by using the Vitek 2 which is automated microbiology system and its applications. The reagent cards used that are incubated and expound automatically. The Vitek 2 system was used according to the manufacturer's instructions; The combination of automated Vitek 2 Technology ready-to-use Vitek 2 identification (ID) and susceptibility (AST) cards provide dependable, accurate ID and AST results for clinically important Gram-positive cocci, Gram-negative cocci, Gram-positive bacilli, Gram-negative bacilli. The sample was culture on special media according to the type of sample on blood agar, MacConkey agar, Chocolate agar and incubated at $35-37^{\circ} \mathrm{C}$ at $18-24$ hours, bacteria were suspend in $2.5 \mathrm{ml}$ of $0.45 \%$ sodium chloride solution. The suspension used in the Vitek 2 system was adjusted to a McFarland standard of 0.5 by using a Densicheek (bioMerieux).

\section{Statistical Analysis}

Used in order that analyze and assess the results they including:

Binomial $(0.50)=$ Frequencies $/$ Descriptive statistics

\section{Descriptive statistics}

statistical tables contain observed frequencies with their percentages.

\section{Inferential statistics}

The accept or reject show by used statistical hypotheses, 0.05 level of significance represent the Persons Chi-Square test $(\chi 2)$.

$P$ value $<0.05$ level of significance was considered statistically significant.

P-value $<0.025$ in 2-sided. 


\section{RESULTS}

In this study, Isolated organism in leukemic children show $18(22.5 \%)$ gram positive and $62(77.5 \%)$ gram negative from the total sample 80(100.0\%) as shown in Table (1).
Table 1. Isolated Organism in Leukemic Children

\begin{tabular}{lccc}
\hline Isolated Organism & No. & $\%$ & P-Value \\
\hline Gram Positive & 18 & 22.5 & \\
Gram Negative & 62 & 77.5 & 0.00 \\
Total & 80 & 100.0 & \\
\hline
\end{tabular}

P- Value $<0.05$

Table 2. Age and Sex Distribution in Leukemic Children

\begin{tabular}{lcccc}
\hline \multirow{2}{*}{ Age Group } & \multicolumn{2}{c}{ Sex } & Total & P-Value \\
\cline { 2 - 3 } & Male No. \% & Female No. \% & & \\
\hline 1 day $-3 Y$ & $19(57.6)$ & $14(42.4)$ & $33(100.0)$ & \\
$4 Y-6 Y$ & $12(63.2)$ & $7(36.8)$ & $19(100.0)$ & \\
$7 Y-9 Y$ & $7(53.8)$ & $6(46.2)$ & $13(100.0)$ & 0.326 \\
$10 Y-12 Y$ & $6(66.7)$ & $3(33.3)$ & $9(100.0)$ & \\
$13 Y-15 Y$ & $1(16.7)$ & $5(83.3)$ & $6(100.0)$ & \\
Total & $45(56.2)$ & $35(43.8)$ & $80(100.0)$ & \\
\hline
\end{tabular}

P-Value $>0.025$ in 2 - sided.

Table 3. The Distribution of Organism according to the type of Sample

\begin{tabular}{|c|c|c|c|c|c|c|c|c|c|}
\hline \multirow[t]{2}{*}{ Organisms } & \multirow[t]{2}{*}{ Total No.\% } & \multicolumn{7}{|c|}{ Type of Sample } & \multirow[b]{2}{*}{$\begin{array}{c}\text { Abscess } \\
\text { No.\% }\end{array}$} \\
\hline & & $\begin{array}{l}\text { Blood } \\
\text { No.\% }\end{array}$ & $\begin{array}{l}\text { Urine } \\
\text { No.\% }\end{array}$ & $\begin{array}{l}\text { Pus } \\
\text { No.\% }\end{array}$ & $\begin{array}{l}\text { Wound } \\
\text { Swab } \\
\text { No.\% }\end{array}$ & $\begin{array}{c}\text { Sputum } \\
\text { No.\% }\end{array}$ & $\begin{array}{c}\text { Ear } \\
\text { Swab } \\
\text { No.\% }\end{array}$ & $\begin{array}{l}\text { Skin } \\
\text { Swab } \\
\text { No.\% }\end{array}$ & \\
\hline \multicolumn{10}{|l|}{ Gram Positive } \\
\hline Staph. aureus & $13(16.2)$ & $10(76.9)$ & $0(0.0)$ & $0(0.0)$ & $1(7.7)$ & $1(7.7)$ & $1(7.7)$ & $0(0.0)$ & $0(0.0)$ \\
\hline Staph. homins & $1(1.3)$ & $0(0.0)$ & $1(100.0)$ & $0(0.0)$ & $0(0.0)$ & $0(0.0)$ & $0(0.0)$ & $0(0.0)$ & $0(0.0)$ \\
\hline Strpto. faecalis & $2(2.5)$ & $1(50.0)$ & $0(00.0)$ & $1(50.0)$ & $(00.0)$ & $0(0.0)$ & $0(0.0)$ & $0(0.0)$ & $0(0.0)$ \\
\hline $\begin{array}{l}\text { Strepto. } \\
\text { pneuomoinae }\end{array}$ & $2(2.5)$ & $1(50.0)$ & $0(0.0)$ & $0(0.0)$ & $0(0.0)$ & $1(50.0)$ & $0(0.0)$ & $0(0.0)$ & $0(0.0)$ \\
\hline \multicolumn{10}{|l|}{ Gram Negative } \\
\hline Escherichia coli & $21(26.3)$ & $4(19.0)$ & $15(71.4)$ & $1(4.8)$ & $1(4.8)$ & $0(0.0)$ & $0(0.0)$ & $0(0.0)$ & $0(0.0)$ \\
\hline K. pneumonia & $13(16.2)$ & $5(38.5)$ & $6(46.2)$ & $0(0.0)$ & $2(15.4)$ & $0(0.0)$ & $0(0.0)$ & $0(0.0)$ & $0(0.0)$ \\
\hline P. aeruginosa & $11(13.8)$ & $5(45.5)$ & $3(27.3)$ & $0(0.0)$ & $0(0.0)$ & $0(0.0)$ & $2(18.2)$ & $0(0.0)$ & $1(9.1)$ \\
\hline Acinetobacter & $8(10.0)$ & $6(75.0)$ & $1(12.5)$ & $0(0.0)$ & $0(0.0)$ & $0(0.0)$ & $0(0.0)$ & $1(12.5)$ & $0(0.0)$ \\
\hline Enterobacter & $5(6.2)$ & $3(60.0)$ & $2(40.0)$ & $0(0.0)$ & $0(0.0)$ & $0(0.0)$ & $0(0.0)$ & $0(0.0)$ & $0(0.0)$ \\
\hline Proteus mirablis & $4(5.0)$ & $0(0.0)$ & $4(100.0)$ & $0(0.0)$ & $0(0.0)$ & $0(0.0)$ & $0(0.0)$ & $0(0.0)$ & $0(0.0)$ \\
\hline $\begin{array}{l}\text { Total (Gram } \\
\text { positive+ Gram } \\
\text { Negative) }\end{array}$ & $80(100.0)$ & $35(43.8)$ & $32(40.0)$ & $2(2.5)$ & $4(5.0)$ & $2(2.5)$ & $3(3.8)$ & $1(1.2)$ & $1(1.2)$ \\
\hline
\end{tabular}

P-Value $=0.003 ;$ P-Value $<0.025$ in 2 - sided 
Table 4. Antimicrobial Susceptibility Pattern of Isolated Gram Positive Bacteria

\begin{tabular}{|c|c|c|c|c|c|c|c|c|}
\hline \multirow{4}{*}{$\begin{array}{l}\text { Antibiotic } \\
\text { Total }\end{array}$} & \multirow{2}{*}{\multicolumn{2}{|c|}{$\frac{\text { Staph aureus }}{(13)}$}} & \multirow{2}{*}{\multicolumn{2}{|c|}{$\frac{\text { Staph. homins }}{\text { (1) }}$}} & \multirow{2}{*}{\multicolumn{2}{|c|}{$\frac{\text { Strepto. faecalis }}{(2)}$}} & \multirow{2}{*}{\multicolumn{2}{|c|}{$\frac{\text { Strept. pneumoniae }}{(2)}$}} \\
\hline & & & & & & & & \\
\hline & $S$ & $\mathrm{R}$ & $S$ & $\mathrm{R}$ & $S$ & $\mathrm{R}$ & $S$ & $\mathrm{R}$ \\
\hline & No. \% & No. \% & No. \% & No. \% & No. \% & No. \% & No. \% & No. \% \\
\hline CTX & $3(23.1)$ & $5(38.1)$ & $0(0.0)$ & $0(0.0)$ & $1(100.0)$ & $0(0.0)$ & $0(0.0)$ & $0(0.0)$ \\
\hline Van & $12(92.3)$ & $1(7.7)$ & $1(100.0)$ & $0(0.0)$ & $1(100.0)$ & $0(0.0)$ & $2(100.0)$ & $0(0.0)$ \\
\hline FOX & $4(30.8)$ & $0(0.0)$ & $0(0.0)$ & $0(0.0)$ & $0(0.0)$ & $0(0.0)$ & $0(0.0)$ & $0(0.0)$ \\
\hline CAZ & $2(15.4)$ & $1(7.7)$ & $0(0.0)$ & $0(0.00$ & $0(0.0)$ & $0(0.0)$ & $0(0.0)$ & $0(0.0)$ \\
\hline$P$ & $0(0.0)$ & $7(53.8)$ & $0(0.0)$ & $0(0.0)$ & $0(0.0)$ & $0(0.00$ & $0(0.0)$ & $2(100.0)$ \\
\hline$C D$ & $6(46.2)$ & $2(15.4)$ & $0(0.0)$ & $0(0.0)$ & $0(0.0)$ & $0(0.0)$ & $3(100.0)$ & $0(0.0)$ \\
\hline AMP & $2(15.4)$ & $0(0.0)$ & $0(0.0)$ & $0(0.0)$ & (100.0) & $0(0.0)$ & $0(0.0)$ & $0(0.0)$ \\
\hline Gen & $7(53.8)$ & $2(15.4)$ & $0(0.0)$ & $1(100.0)$ & $2(100.0)$ & $0(0.0)$ & $1(100.0)$ & $0(0.0)$ \\
\hline $\mathrm{Li}$ & $4(30.8)$ & $2(15.4)$ & $0(0.0)$ & $0(0.0)$ & $1(100.0)$ & $0(0.0)$ & $0(0.0)$ & $0(0.0)$ \\
\hline CRO & $2(15.4)$ & $6(46.2)$ & $0(0.0)$ & $0(0.0)$ & $1(100.0)$ & $0(0.0)$ & $0(0.00$ & $0(0.0)$ \\
\hline $\mathrm{PI}$ & $1(7.7)$ & $1(7.7)$ & $0(0.0)$ & $0(0.0)$ & $1(100.0)$ & $0(0.0)$ & $0(0.0)$ & $0(0.0)$ \\
\hline IPM & $1(7.7)$ & $0(0.00$ & $0(0.00$ & $0(0.0)$ & $1(100.0)$ & $0(0.0)$ & $0(0.0)$ & $0(0.0)$ \\
\hline $\mathrm{E}$ & $2(15.4)$ & $1(7.7)$ & $0(0.0)$ & $1(100.0)$ & $0(0.00$ & $2(100.0)$ & $0(0.0)$ & $0(0.0)$ \\
\hline TM & $3(23.1)$ & $0(0.0)$ & $1(100.0)$ & $0(0.0)$ & $1(100.0)$ & $0(0.0)$ & $0(0.0)$ & $0(0.0)$ \\
\hline Cip & $5(38.1)$ & $2(15.4)$ & $1(100.0)$ & $0(0.0)$ & $1(100.0)$ & $0(0.0)$ & $0(0.0)$ & $0(0.0)$ \\
\hline OX & $0(0.0)$ & $4(30.8)$ & $0(0.0)$ & $1(100.0)$ & $0(0.0)$ & $0(0.0)$ & $0(0.0)$ & $0(0.0)$ \\
\hline TE & $2(15.4)$ & $2(15.4)$ & $0(0.0)$ & $1(100.0)$ & $0(0.0)$ & $0(0.0)$ & $0(0.0)$ & $0(0.00$ \\
\hline TEC & $0(0.0)$ & $0(0.0)$ & $0(0.0)$ & $0(0.0)$ & $1(100.0)$ & $0(0.0)$ & $0(0.0)$ & $0(0.0)$ \\
\hline Tig & $3(23.1)$ & $0(0.0)$ & $0(0.0)$ & $0(0.0)$ & $0(0.0)$ & $0(0.0)$ & $0(0.0)$ & $0(0.0)$ \\
\hline FA & $1(7.7)$ & $1(7.7)$ & $0(0.0)$ & $0(0.0)$ & $0(0.0)$ & $0(0.0)$ & $0(0.0)$ & $1(100.0)$ \\
\hline
\end{tabular}




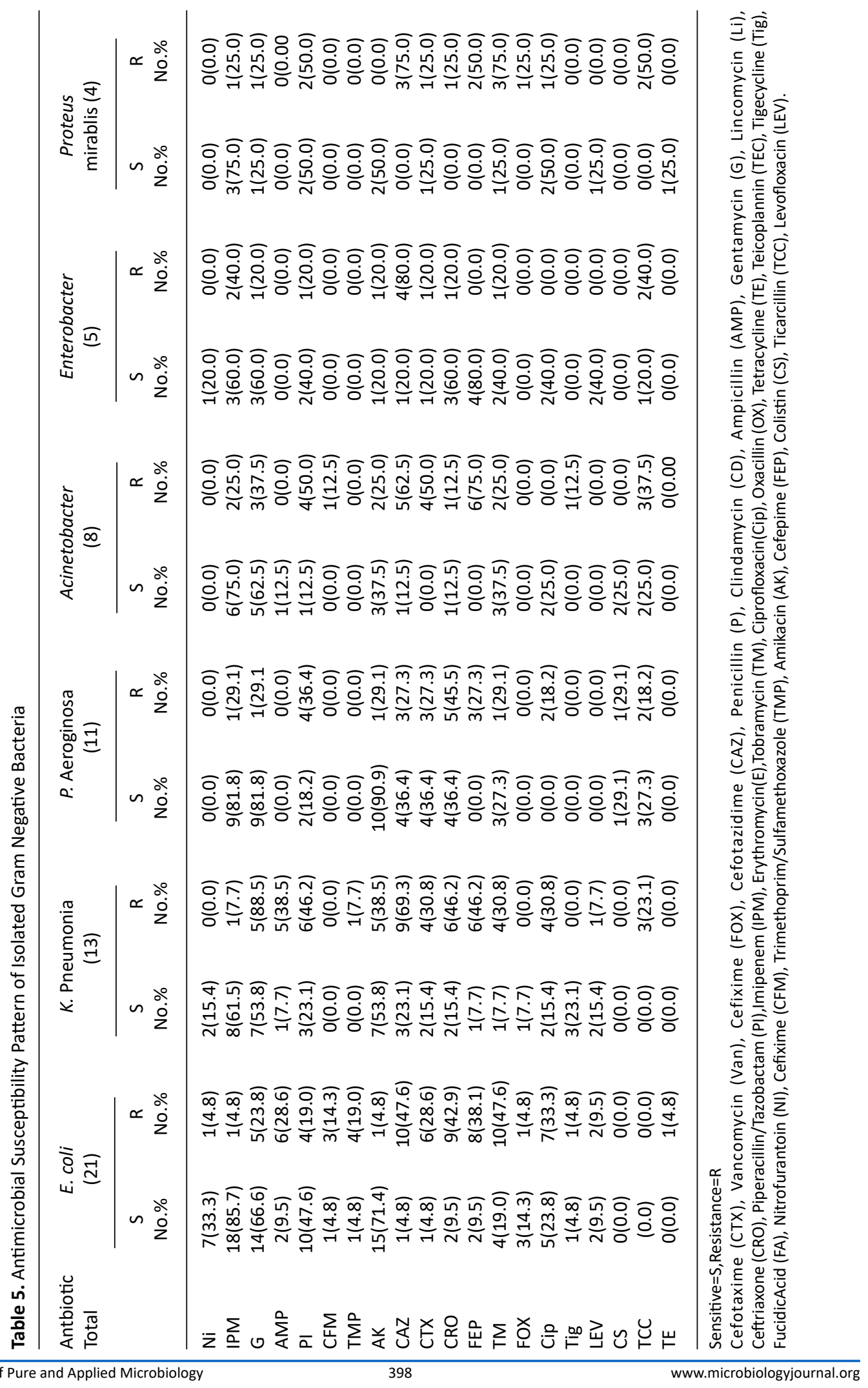




\section{DISCUSSION}

The prevalence in patients with cancer is $5.7-44 \%$ of bacteremia according to the global reports. ${ }^{19,20}$ The percentage of gram negative bacteria is more than gram positive bacteria which represent $62(77.5 \%), 18(2.5 \%)$ respectively show in Table (1) and the p-value is 0.00 which represent significant. According to the study the result has slightly more incidents in males number were 45 while females number were 35 from the whole number of specimen was 80 patients and agreement with Marcotte (1), Muhammed, ${ }^{2}$ Ahamed, ${ }^{4}$ Martinez-Laperche, ${ }^{7}$ Sevan ${ }^{21}$ show in Table (2). During the last few decades have seen diagnosed with cancer in the survival of children with the 5 -year survival rate approaching $80 \%{ }^{22}$ Incidence rates increase to a peak around age 3-4 years and then decline. ${ }^{23}$ Also, the Table (2) appear the most age group gives positive result between ( 1 day- 3 years) which represent $33(100.0 \%$ ) this agreement with Ahamed. ${ }^{4}$ The $p$-value is 0.326 which, is non-significant in 2-sided. In our study, the multiple samples were associated with $70.5 \%$ of positive result Hosseini. ${ }^{19}$ In present study $35(43.8 \%)$ of 80 blood cultures were positive which is similar to other studies Eslami Nejad, ${ }^{13}$ El-Mahallawy. ${ }^{24}$ The most Gram positive bacteria was isolated is Staphylococcus aureus $13(16.2 \%)$ and the most gram negative bacteria from the total isolates is Escherichia coli 21(26.3\%), Klebsiella pneumoniae 13 (16.2\%), Pseudomonas aeruginosa $11(13.8 \%)$ from the total results 80(100.0\%) these show in Table (3) and the result agreement with Ahmed, ${ }^{4}$ Tezcan..$^{25}$ The p-value is 0.003 , which is significant gram positive and gram negative bacteria in relation with multiple sample. In Table (4) the antibiotic susceptibility of isolated most effects to Staphylococcus aureus is Vancomycin $12(92.3 \%)$, Gentamycin 7(53.8\%), Clindamycin 6(46.2\%), Ciprofloxacin 5(38.1\%), Lincomycin 4(30.8\%), Cefixime 4(30.8\%) and the more resistance is Penicillin $7(53.8 \%)$, Ceftriaxone 6(46.2\%), Cefotaxime 5(38.1\%), Oxacillin 4(30.8\%) which agree with Eslami Nejad. ${ }^{13}$ The most antibiotic sensitive gram negative organism is Escherichia coli to Imipenem 18(85.7\%), Amikacin 15(71.4\%), Gentamycin 14(66.6\%),
Piperacillin/Tazobactam 10(47.6\%) and Klebsiella pneumoniae sensitive to Imipenem 8(61.5\%), Amikacin 7(53.8\%), Gentamycin 7(53.8\%), Piperacillin/Tazobactam 3(23.1\%), pseudomonas aeruginosa sensitive to Amikacin 10(90.9\%), Imipenem 9(81.8\%), Gentamycin 9(81.8\%). The Escherichia coli is resistance to Cefotazidime 10(47.6\%), Tobramycin 10(47.6\%), Cefepime $8(38.1 \%)$, Ceftriaxone 7(33.3\%), Ciprofloxacin $7(33.3 \%)$, and Klebsiella pneumoniae is resist to Cefotazidime 9(69.3\%), Piperacillin/Tazobactam 6(46.2\%), Cefepime 6(46.2\%), Ciprofloxacin 6(46.2\%), Tobramycin 4(30.8\%). Pseudomonas aeruginosa is resist to Ceftriaxone $5(45.5 \%)$, Piperacillin/Tazobactam 4(36.4\%), Cefepime $3(27.3 \%)$, these result agreement with Al-Ouqaili. ${ }^{26}$ these bacteria is multidrug resistant shown in Table (5).

\section{CONCLUSION}

In conclusion, in the present study the gram negative bacteria is more than gram positive bacteria and especially effective with Escherichia coli, and Staphylococcus aureus, in males for the age group one day to three years. And the most antibiotic sensitive to Escherichia coli is Imipenem, Amikacin, Gentamycin, Piperacillin/Tazobactam and resist to Cefotazidime, Tobramycin, Cefepime, Ceftriaxone, Ciprofloxacin and Staphylococcus aureus most sensitive to Vancomycin, Gentamycin, Clindamycin, and resist to Penicillin, Cefotaxime, Ceftriaxone, Oxacillin.

\section{ACKNOWLEGMENTS}

The authors gratefully acknowledge all the staff in the Department of Bacteriology Laboratory in Central Teaching Hospital of Pediatrics, Baghdad, Iraq.

\section{CONFLICT OF INTEREST}

The authors declare that there is no conflict of interest.

\section{AUTHORS' CONTRIBUTION}

All authors listed have made a substantial, direct and intellectual contribution to the work, and approved it for publication. 


\section{FUNDING}

None.

\section{DATA AVAILABILITY}

All datasets generated or analyzed during this study are included in the manuscript.

\section{ETHICS STATEMENT}

Not applicable.

\section{REFERENCES}

1. Marcotte EL, Ritz B, Cockburn M, Yu F, Heck JE. Exposure to Infections and Risk of Leukemia in Young Children. Cancer Epidemiol Biomarkers Prev. 2014;23(7):1195-1203. doi: 10.1158/1055-9965.EPI13-1330

2. Muhammed NA, Farhan MB, Shabeeb ZA. Isolation and Identification of Gram-Negative Bacteria Responsible for Bacteremia in Leukemia Patient and Detection of Procalcitonin Levels in Serum of Leukemic Patients. Saudi Journal of Pathology and Microbiology. 2017;2(5):153-166.

3. Azevedo L, ed. Sepsis - An Ongoing and Significant Challenge. 2012. doi: 10.5772/2958

4. Ahamed F, Begum SA, Jobayer M, et al. Bacteriological profile by blood culture among acute lymphoblastic leukemic children hospitalized with neutropenia and fever in a tertiary level hospital, Bangladesh. Bangladesh J Med Microbiol. 2017;9(1):9-12. doi: 10.3329/bjmm.v9i1.31333

5. Corey GR. Staphylococcus aureus Bloodstream Infections: Definitions and Treatment. Clin Infect Dis. 2009;48(Supplement_4):S254-S259. doi: $10.1086 / 598186$

6. Belson M, Kingsley B, Holmes A. Risk Factors for Acute Leukemia in Children: A Review. Environ Health Perspect. 2007;115(1):138-145. doi: 10.1289/ ehp.9023

7. Martinez-Laperche C, Gomez-Garcia AM, Lassaletta $A$, et al. Detection of occult cerebrospinal fluid involvement during maintenance therapy identifies a group of children with acute lymphoblastic leukemia at high risk for relapse. Am J Hematol. 2013;88(5):359364. doi: 10.1002/ajh.23407

8. Geddes Am, Ellis CJ. Infection in Immunocompromised Patients. QJM: An International Journal of Medicine. 1985;55(1):5-14. doi: 10.1093/oxfordjournals.qjmed. a067853

9. Ashour HM, El-Sharif A. Microbial Spectrum and Antibiotic Susceptibility Profile of Gram-Positive Aerobic Bacteria Isolated From Cancer Patients. J Clin Oncol. 2007;25(36):5763-5769. doi: 10.1200/ JCO.2007.14.0947

10. Norgaard M. Risk of Infections in Adult Patients with Haematological Malignancies. The Open Infectious Diseases Journal. 2012;6(1):46-51. doi: 10.2174/1874279301206010046
11. Asturias EJ, Corral JE, Quezada J. Evaluation of six risk factors for the development of bacteremia in children with cancer and febrile neutropenia. Curr Oncol. 2010;17(2):59-63. doi: 10.3747/co.v17i2.453

12. Tapper ML, Armstrong D. Bacteremia Due to Pseudomonas aeruginosa Complicating Neoplastic Disease: A Progress Report. The Journal of Infectious Diseases. 1974;130(Suppl):S14-S23. doi: 10.1093/ infdis/130.Supplement.S14

13. Nejad ZE, Ghafouri E, Farahmandi-Nia Z, Kalantari $B$, Saffari F. Isolation, Identification, and Profile of Antibiotic Resistance of Bacteria in Patients with Cancer. Iranian Journal of Medical Sciences. 2010;35(2):109-115.

14. Nijhuis CO, Kamps WA, Daenen SMG, et al. Feasibility of Withholding Antibiotics in Selected Febrile Neutropenic Cancer Patients. J Clin Oncol. 2005;23(30):7437-7444. doi: 10.1200/JCO.2004.00.5264

15. Gustinetti G, Mikulska M. Bloodstream infections in neutropenic cancer patients: A practical update. Virulence. 2016;7(3):280-297. doi: 10.1080/21505594.2016.1156821

16. Castagnola E, Caviglia I, Pescetto L, Bagnasco F, Haupt R, Bandettini R. Antibiotic susceptibility of Gramnegatives isolated from bacteremia in children with cancer. Implications for empirical therapy of febrile neutropenia. Future Microbiol. 2015;10(3):357-365. doi: $10.2217 /$ fmb.14.144

17. Bow EJ. There should be no ESKAPE for febrile neutropenic cancer patients: the dearth of effective antibacterial drugs threatens anticancer efficacy. J Antimicrob Chemother. 2013;68(3):492-495. doi: 10.1093/jac/dks512

18. Al-Qaysi AMK, Al-Ouqaili MTS, Al-Meani SAL. Ciprofloxacin- and gentamicin-mediated inhibition of Pseudomonas aeruginosa biofilms is enhanced when combined the volatile oil from Eucalyptus camaldulensis. Systematic Reviews in Pharmacy. 2020;11(7):98-105.

19. Hosseini SMJ, Ranjbar R, Ghasemi H, Saadat Ar, Soleymani R. A Study On The Prevalence And Etiology Of Fever In Patients Hospitalized With Fever And Neutropenia In Baqyiatallah Hospital During 19952005. Journal Of Ilam University Of Medical Sciences. 2006;14(3):8-11.

20. Kim YH, Lee HD, Hah JO. Bacteremia in pediatric cancer patients: causative organisms and antibiotic sensitivities. Korean J Pediatr. 2005;48(6):619-623.

21. Abdallah SNA, Al-Dabbag R, Baqir HI. Nosocomial bacteremia in leukopenic patients with leukemia in Baghdad teaching hospital. The Iraqi Postgraduate Medical Journal. 2008;7(4):5.

22. Stabell N, Nordal E, Stensvold E, et al. Febrile neutropenia in children with cancer: A retrospective Norwegian multicentre study of clinical and microbiological outcome. Scand J Infect Dis. 2008;40(4):301-307. doi: 10.1080/00365540701670436

23. Shah A, Coleman MP. Increasing incidence of childhood leukaemia: a controversy re-examined. $\mathrm{Br} J$ Cancer. 2007;97(7):1009-1012. doi: 10.1038/sj.bjc.6603946 
24. El-Mahallawy H, Sidhom I, El-Din NHA, Zamzam M, El-Lamie MM. Clinical and microbiologic determinants of serious bloodstream infections in Egyptian pediatric cancer patients: a one-year study. Int J Infect Dis. 2005;9(1):43-51. doi: 10.1016/j.ijid.2003.11.010

25. Tezcan G, Kupesiz A, Ozturk F, et al. Episodes of fever and neutropenia in children with cancer in a tertiary care medical center in Turkey. $J$ Pediatr Hematol Oncol. 2006;23(3):217-229. doi: $10.1080 / 08880010500506719$
26. Al-Ouqaili MTS, Khalaf EA, Al-Kubaisy SH. DNA Sequence Analysis of BlaVEB Gene Encoding Multi-drug Resistant and Extended-spectrum $\beta$-lactamases Producer Isolates of and Extendedspectrum $\beta$-lactamases Producer Isolates of Enterobacteriaceae and Pseudomonas aeruginosa. The Open Microbiology Journal. 2020;14(1):40-47. doi: $10.2174 / 1874285802014010040$ 